\title{
Efficacy of Jatropha curcas Latex Cream in The Epithelialization Phase of Wound Healing in Mice Skin
}

\author{
Muhammad N. Salim ${ }^{1}$, Moma Silvia ${ }^{2}$, Dwinna Aliza ${ }^{1}$, Dian Masyitha ${ }^{3}$, Cut D. Iskandar ${ }^{3}$, Rusli Rusli $^{4}$, Sugito \\ Sugito $^{4}$, Muhammad Hasan ${ }^{4}$, Mustafa Sabri ${ }^{5}$, and Abdul Harris ${ }^{6}$ \\ ${ }^{1}$ Laboratory of Pathology, Faculty of Veterinary Medicine, Universitas Syiah Kuala, Banda Aceh 23111, Indonesia. \\ ${ }^{2}$ Undergraduate Student, Faculty of Veterinary Medicine, Universitas Syiah Kuala, Banda Aceh 23111, Indonesia. \\ ${ }^{3}$ Laboratory of Histology, Faculty of Veterinary Medicine, Universitas Syiah Kuala, Banda Aceh 23111, Indonesia. \\ ${ }^{4}$ Laboratory of Clinical Pathology, Faculty of Veterinary Medicine, Universitas Syiah Kuala, Banda Aceh 23111, Indonesia. \\ ${ }^{5}$ Laboratory of Anatomy, Faculty of Veterinary Medicine, Universitas Syiah Kuala, Banda Aceh 23111, Indonesia. \\ ${ }^{6}$ Laboratory of Pharmacology, Faculty of Veterinary Medicine, Universitas Syiah Kuala, Banda Aceh 23111, Indonesia
}

\begin{abstract}
The objective of the present research was to find out the efficacy of Jatropha latex cream in the epithelialization phase of wound healing in mice skin. A total of 9 male mice aged 2-3 months old and the bodyweight of 25-40 g were divided into three treatment groups. Group A was given basic cream, group B was given Jatropha latex cream (10\%), and group C was given sulfadiazine. The $2 \mathrm{~cm}$ incision wound was made in the paravertebral area. Wound therapy was carried out twice a day for 7 days. All quantitative data were measured using ANOVA then followed by the Duncan test. The number of angiogenesis on A, B, and $\mathrm{C}$ was $4.67 \pm 1.20 ; 12.78 \pm 2.52$; and $11.33 \pm 2.33$, while a number of fibroblasts were $179.56 \pm 12.69 ; 90.56 \pm 8.23$; and 99.11 \pm 7.04 , respectively. The average deposition of collagen was $1.46 \pm 0.12 ; 1.89 \pm 0.10$; and $1.74 \pm 0.06$, respectively. The statistical test showed that the number of angiogenesis, fibroblast, and deposition of collagen on group B was significantly different $(\mathrm{P}<0.05)$ compared to group A and showed no significant difference compared to group $\mathrm{C}(\mathrm{P}>0.05)$. In conclusion, Jatropha latex cream $(10 \%)$ able to accelerate the epithelialization phase of wound healing in mice skin.
\end{abstract}

Keywords: Jatropha curcas latex cream, angiogenesis, fibroblast, collagen.

\section{Introduction}

Wounds namely damage or disruption of the integrity of the skin and surrounding tissue so that it is followed by a wound-healing reaction [1]. Wounds will cause problems if the treatment is not good, causing chronic wounds due to not achieving the process of complete wound closure [2].

The wound closure process is a complex cellular process to restore the integrity of the structure, and function of damaged tissue through several phases of wound healing $[3,4]$. These phases are the inflammatory, proliferation, and maturation phases [5]. Epithelialization is the process of epithelial tissue growth covering the surface of the wound that occurs in the proliferation phase and is the main parameter of wound healing [6].

Jatropha curcas can be an alternative wound healing because in the latex there are bioactive compounds needed in the wound healing process. The bioactive compounds are alkaloids, saponins, flavonoids, and tannins [7]. Flavonoids, saponins, and tannins play a role in the process of wound healing that affects the process of epithelialization [8].

Flavonoids and saponins can accelerate migration and proliferation of fibroblast cells into the wound area and increase collagen synthesis so that it can accelerate the process of repair of epithelial surfaces [9, 10]. Tannin has antibacterial and angiogenic activities so that it promotes tissue restoration [11].

Previously study indicated latex of $J$. curcas have proven to accelerate the inflammatory phase [12], epithelial phase $[13,14]$, and angiogenesis activity [15]. This causes that the latex of $J$. curcas effective to be used for topical therapy on wound healing in mice skin. Based on the description above it is necessary to research the efficacy the latex of Jatropha cream on epithelialization of wound healing incision of mice skin.

\section{Materials and Methods}

\subsection{Ethical approval}

This research received an ethical clearance approval certificate for animal subjects from the Animal Ethics Committee of Faculty of Veterinary Medicine, Syiah Kuala University, Banda Aceh, Indonesia (Approval No. 004/KEPH-C/VII/2017).

Corresponding author:mnursalim@unsyiah.ac.id 


\subsection{Cream preparation}

Jatropha curcas latex cream and cream base are formulated in the method of oil base in water $(\mathrm{o} / \mathrm{w})$ using oil phase ingredients (stearic acid, cerae albi, and vaseline albi) and water phase (triethanolamine, distilled water, propylene glycol, and nipagin). The cream is put into a sterile cream bottle that is tightly closed and stored at room temperature.

\subsection{Animal subjects preparation}

This study used 9 male mice (Mus musculus), aged 2-3 months with a weight of 25-40 grams, adapted for 7 days, provided with standard diet and given ad libitum access to food and water.

For incision wound making on mice, the backs of mice were shaved, cleaned with $70 \%$ alcohol. All mice were anesthetized with pirlocaine cream. The wound skin incision was performed $2.0 \mathrm{~cm}$ in length until subcutaneous on the paravertebral of each mice. The wound was immediately smeared with cream according to the treatment group.

A total of 9 male mice were divided into three treatment groups, with each treatment group consisted of three replications. Treatment I (negative control), incision wound smeared with cream base (A), treatment II smeared with $J$. curcas latex $10 \%$ (B), and treatment III (positive control) smeared with $1 \%$ sulfadiazine (C). The treatment was conducted 2 daily with an interval of $12 \mathrm{~h}$ for 7 days.

\subsection{Histopathological slides preparation}

The wounded skin was sampled after the mice were euthanized for conducting histopathological slides. Procedure making histopathological preparations refers to standard methods [12]. The slides were evaluated by staining with Hematoxylin-eosin (HE) and Masson's trichrome (MT).

The parameters observed were collagen connective tissue deposition, scoring criteria according to Sabirin et al. [2]. The histological criteria are as follows: collagen deposition score: $(>25 \%=1) ;(25-50 \%=2) ;(51-75 \%=$ $3)$ and $(>75 \%=4)$. While the number of angiogenesis and the number of fibroblasts were counted as many as three visual fields of microscopic. Data were analyzed using analysis of variance (ANOVA) and continues using the Duncan test to find means that are significantly different between treatment.

\section{Results and Discussion}

\subsection{Angiogenesis}

Histopathological observations of wound healing in mice's skin on the 7th day of treatment, on the wound, were found new capillaries formation or angiogenesis. Statistical analysis of ANOVA groups A, B, and C showed a very significant effect on angiogenesis
$(\mathrm{P}<0.01)$. The Duncan test showed that the angiogenesis rates in the A and B groups were significantly different, group $\mathrm{A}$ and $\mathrm{C}$ were also significantly different, but between $\mathrm{B}$ and $\mathrm{C}$ group were not significantly different (P> 0.05) as shown in Table 1.

Table 1. Description mean $\pm \mathrm{SD}$ and statistical analysis of angiogenesis in wound healing of the mice skin on day 7

\begin{tabular}{cc}
\hline Treatment Group & Angiogenesis \\
\hline A & $4,67 \pm 1,20^{\mathrm{b}}$ \\
B & $12,78 \pm 2,52^{\mathrm{a}}$ \\
C & $11,33 \pm 2,33^{\mathrm{a}}$
\end{tabular}

aa: Values in the same column with different letters are no significant difference $(\mathrm{P}>0.05)$

ab: Values in the same column with different letters are a significant difference $(\mathrm{P}<0.05)$

A: Negative control group: cream base

B: Treatment group: $10 \%$ J. curcas latex cream

C: Positive control group: $1 \%$ sulfadiazine cream

Control group (A) with cream base treatment was seen with a small amount of new capillaries formation which was $4.67 \pm 1.20$ (Figure 1a), compared with B group, new capillaries formation was seen as much as $12.78 \pm 2.52$ (Figure $1 b$ ). The $\mathrm{C}$ group also saw a large number of new capillaries formation of $11.33 \pm 2.33$ (Figure 1c).

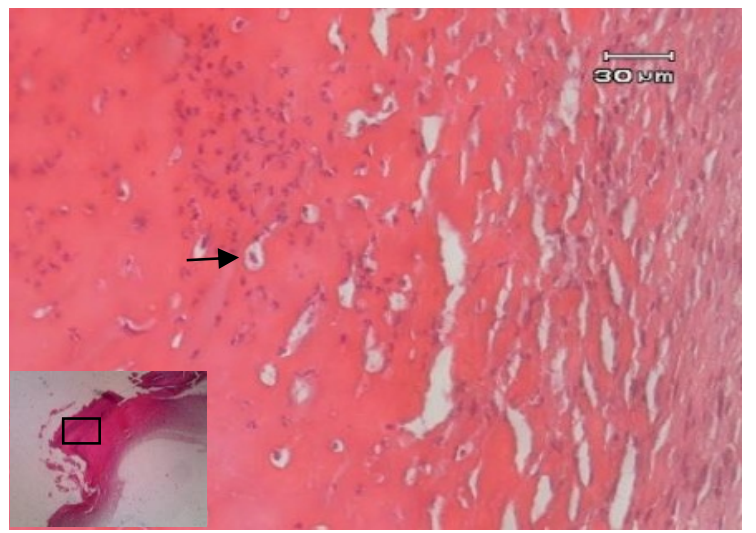

Figure 1a. Angiogenesis photomicrograph (arrow), wound healing in mice skin on the 7th day of cream base treatment (HE staining, 400X).

The angiogenesis rate was low in the A group because in the cream base there were only antibacterial compounds, but there were no bioactive compounds that acted as anti-inflammatory so that the long inflammatory phase that caused the proliferation phase also lasted a long time, this resulted in low new capillaries formation. The high rate of angiogenesis in the B group treated by $10 \%$ $J$. curcas latex cream because in the $J$. curcas latex there were bioactive compounds that could stimulate the proliferation of new capillaries formation. 


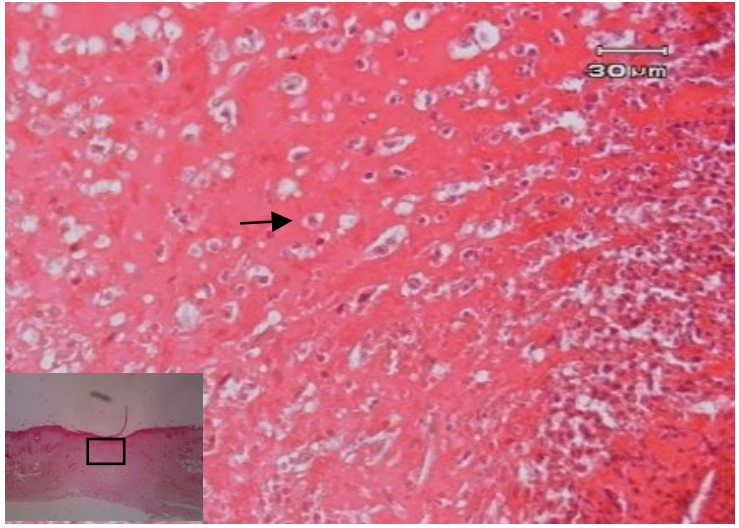

Figure 1b. Angiogenesis photomicrograph (arrow), wound healing in mice skin on the 7th day of $10 \%$ J. curcas latex cream treatment (HE staining, 400X).

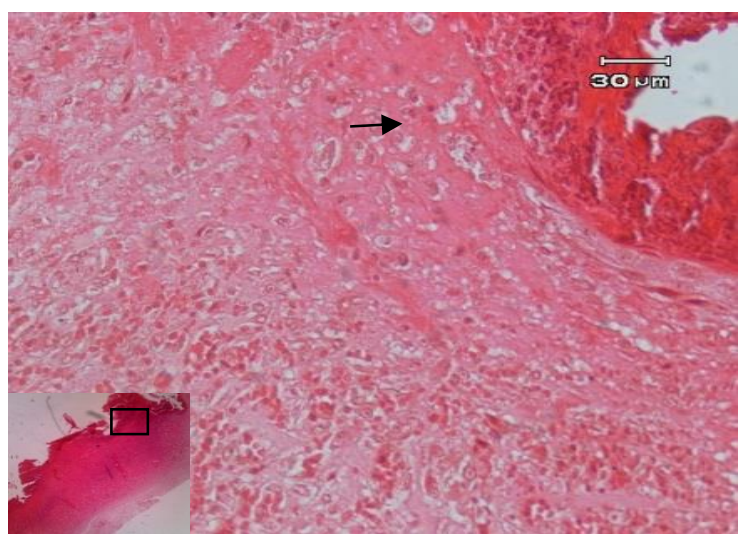

Figure 1c. Angiogenesis photomicrograph (arrow), wound healing in mice skin on the 7th day of sulfadiazine $1 \%$ treatment (HE staining, 400X).

Previously our research noted the cream from $10 \%$ and $15 \% \mathrm{~J}$. curcas latex have angiogenesis activity in wound healing in mice skin [15]. Bioactive compounds contained in $J$. curcas latex are alkaloids, saponins, flavonoids, and tannins [7]. The saponin content in $J$. curcas latex cream plays a role in stimulating the growth of new cells [16]. Saponins function to stimulate the formation of new cells or growth factors, thereby causing multiplication and growth of blood vessel endothelial cells [17].

The presence of new or neovascular blood vessels has an important role to bring the ingredients and nutrients needed in the healing process. Macrophages release the angiogenesis factor (AGF) which stimulates the formation of endothelial cells of blood vessels. Macrophages and AGF together accelerate the healing process [18]. Tannin also has anti-bacterial and angiogenic activity so that it promotes tissue restoration [11].

The rate of angiogenesis in $\mathrm{C}$ group with $1 \%$ sulfadiazine was not significantly different from $\mathrm{B}$ group because in sulfadiazine there was a combination of silver and sulfadiazine compounds [19]. Silver sulfadiazine is also able to stimulate cells such as macrophages to produce growth factors and cytokines in the process of wound healing such as TGF- $\beta$, EGF, IL-1, IL-4, and IL- 8 so that along with antibacterial properties can accelerate the process of wound healing [20]. Besides that, silver sulfadiazine has a positive effect on neovascular proliferation [21]. However, due to its anti-infection properties, silver sulfadiazine does not provide moisture to the wound so it does not support a faster healing process [22].

\subsection{Fibroblasts}

Histopathological observations of wound healing in mice's skin on the 7th day of treatment at the wound site found fibroblasts cells that spread on the surface of the wound tissue. ANOVA statistical analysis proved a very significant effect between the three treatment groups of A, $\mathrm{B}$, and $\mathrm{C}$ on the number of fibroblast cells $(\mathrm{P}<0.01)$. The site number of fibroblast cells was highest in the A group, followed by $\mathrm{C}$ and $\mathrm{B}$, but between $\mathrm{B}$ and $\mathrm{C}$ groups were not significantly different $(\mathrm{P}>0.05)$ as shown in Table 2.

Table 2. Description mean $\pm \mathrm{SD}$ and statistical analysis of fibroblasts in wound healing of the mice skin on day 7

\begin{tabular}{cc}
\hline Treatment Group & Fibroblasts \\
\hline A & $179,56 \pm 12,69^{\mathrm{a}}$ \\
B & $90,56 \pm 8,23^{\mathrm{b}}$ \\
C & $99,11 \pm 7,04^{\mathrm{b}}$
\end{tabular}

aa: Values in the same column with different letters are no significant difference $(\mathrm{P}>0.05)$

ab: Values in the same column with different letters are a significant difference $(\mathrm{P}<0.05)$

A: Negative control group: cream base

B: Treatment group: $10 \%$ J. curcas latex cream

C: Positive control group: $1 \%$ sulfadiazine cream

The negative control (A) group with cream base treatment was seen in large, tight, and evenly distributed fibroblasts in the wound (Figure 2a), compared B groups with $10 \% \mathrm{~J}$. curcas latex cream treatment (Figure $2 \mathrm{~b}$ ) and c groups with sulfadiazine $1 \%$ treatment (Figure 2c).

Fibroblasts are cells that play an important role and are responsible for producing protein structure products that will be used for tissue reconstruction. The main process of fibroblast growth occurs on the 7-14th day after injury [23]. The high number of fibroblasts in the A group indicates that there is still a proliferation of fibroblast cells to form collagen connective tissue. Whereas in B and C groups the number of fibroblasts has begun to decrease, fibroblast cells become inactive into fibrocytes after the formation of collagen connective tissue. Flavonoids can accelerate the migration and proliferation of fibroblast cells into the wound area and increase collagen synthesis for the epithelialization wound process [10]. Furthermore, granulation tissue will be formed, namely inflammatory cells, especially macrophage cells will release substances that will trigger angioblasts and fibroblasts [5]. 


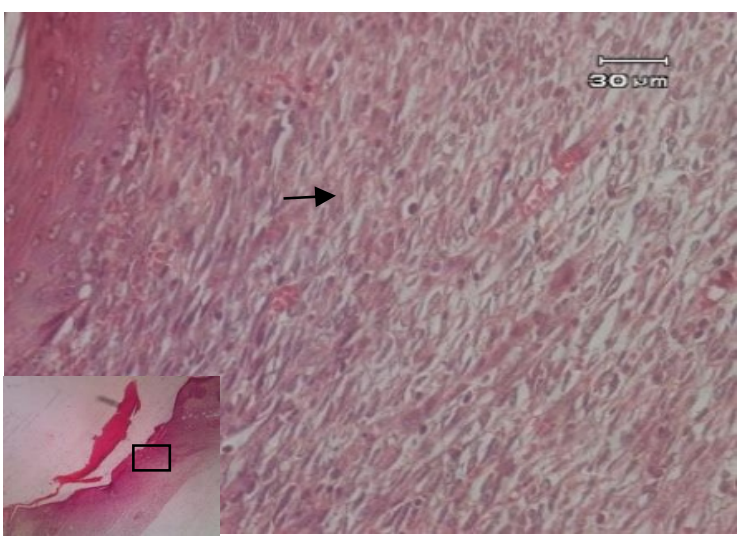

Figure 2a. Photomicrograph of fibroblasts on wound skin on the 7th day of cream base (A) treatment (HE staining, 400X).

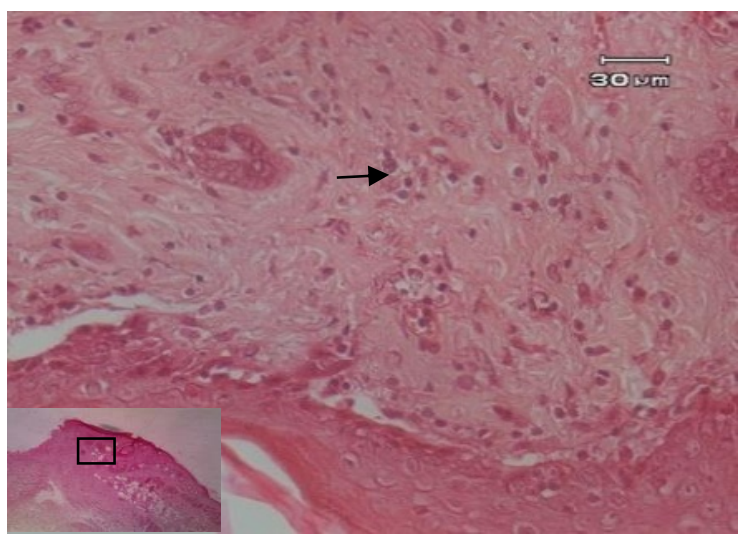

Figure 2b. Photomicrograph of fibroblasts on wound skin on the 7th day of $10 \%$ J. curcas latex cream (B) treatment (HE staining, 400X).

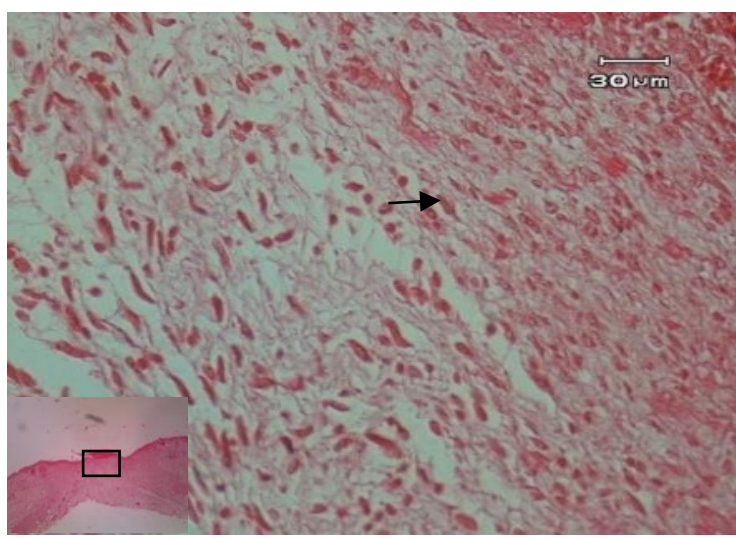

Figure 2c. Photomicrograph of fibroblasts on wound skin on the 7 th day of $1 \%$ sulfadiazine cream $(\mathrm{C})$ treatment (HE staining, 400X).

The B and C groups statistically showed no difference because sulfadiazine is a sulfonamide class that has broadspectrum antibacterial properties which can accelerate wound healing [24]. Besides that silver sulfadiazine has a positive effect on the proliferation of fibroblasts that produce collagen and fibronectin [20, 25].

\subsection{Deposition of collagen}

Histopathological observations of collagen deposition scoring on the 7th day of healing wounds of mice's skin wounds are shown in Table 3 . Statistical analysis of ANOVA showed a very significant effect between A, B, and $\mathrm{C}$ groups on collagen connective tissue deposition ( $\mathrm{P}$ $<0.01)$. Duncan test showed the rate collagen deposition scoring between A and B group were significantly different, A and B group were also significantly different, but between $\mathrm{B}$ and $\mathrm{C}$ group were not significantly different $(\mathrm{P}>0.05)$.

Table 3. Description mean $\pm \mathrm{SD}$ and statistical analysis of collagen deposition scoring in wound healing of the mice skin on day 7.

\begin{tabular}{cc}
\hline Treatment Group & $\begin{array}{c}\text { Collagen deposition } \\
\text { scoring }\end{array}$ \\
\hline A & $1,46 \pm 0,12^{\mathrm{b}}$ \\
B & $1,89 \pm 0,10^{\mathrm{a}}$ \\
C & $1,74 \pm 0,06^{\mathrm{a}}$
\end{tabular}

aa: Values in the same column with different letters are no significant difference $(\mathrm{P}>0.05)$

ab: Values in the same column with different letters are significant difference $(\mathrm{P}<0.05)$

A: Negative control group: cream base

B: Treatment group: $10 \%$ J. curcas latex cream

C: Positive control group: $1 \%$ sulfadiazine cream

The negative control (A) group with cream base treatment showed moderate collagen density and unevenly distributed collagen on the surface of the wound tissue (Figure 3a). The B group with $10 \%$ J. curcas latex cream was found collagen density was spread evenly and tightly across the wound surface (Figure $3 \mathrm{~b}$ ). The $\mathrm{C}$ group with $1 \%$ sulfadiazine treatment were found the density of collagen is moderately dense and evenly spread on the surface of the wound tissue (Figure 3c)

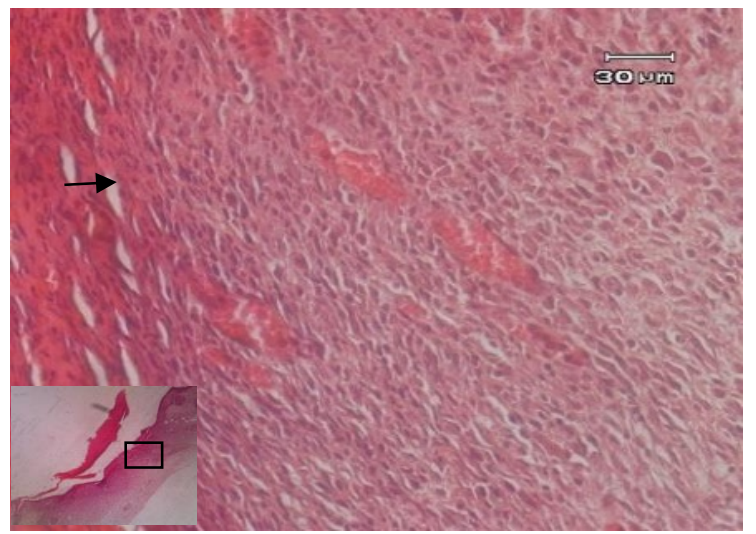

Figure 3a. Photomicrograph of collagen deposition on wound skin on the 7th day of cream base (A) treatment (HE staining, 400X). 


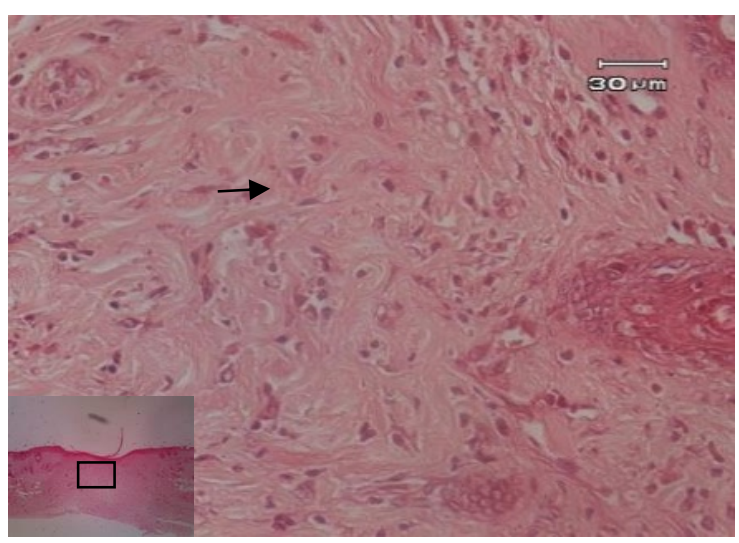

Figure 3b. Photomicrograph of collagen deposition on wound skin on the 7th day of $10 \% \mathrm{~J}$. curcas latex cream (B) treatment (HE staining, 400X).

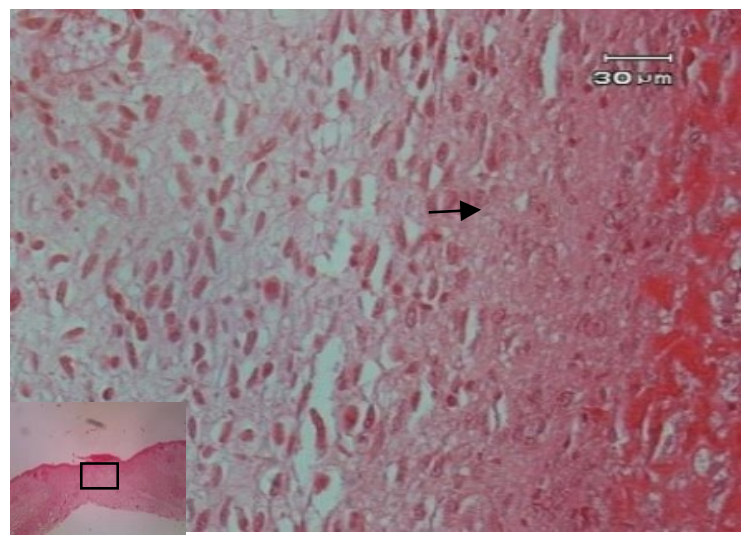

Figure 3c. Photomicrograph of collagen deposition on wound skin on the 7 th day of $1 \%$ sulfadiazine cream (C) treatment (HE staining, 400X).

The results of this collagen deposition scoring study correlated positively with research conducted by Napanggala et al. [17] the bioactive content in J. curcas can increase collagen deposition. The bioactive compound, saponin, can accelerate the process of angiogenesis and the formation of collagen in the wound healing process of the rat. According to Takahashi et al. [9], saponins have antimicrobial and antioxidant effects that can increase collagen content to accelerate the process of repair or recovery of the epithelial of wound. Collagen is the most protein in the extracellular matrix of the skin and serves to fill the extracellular matrix. In the process of wound healing, collagen is formed since the 3rd day and the amount will be seen to be noticeable on the 7 th day, and it starts to be stable and organized around the 14th day [2]. Shetty et al. [26] reported that the crude bark extract of $J$. curcas was very effective in accelerating the wound healing process and have a beneficial effect on various phases of wound healing such as fibroflasia, collagen synthesis and wound contraction.

\section{Conclusion}

Based on the results of the study it can be concluded that Jatropha curcas latex cream $(10 \%)$ able to accelerate the epithelialization phase of wound healing in mice skin.

\section{Acknowledgments}

The authors are thankful to Directorate General of Strengthening Research and Development, Ministry of Research, Technology and Higher Education Republic Indonesia for giving a grant funding to carry out this research.

\section{References}

1. Velnar T, Bailey T, Smrkolj V: The wound healing process: An overview of cellular and molecular mechanism. J. Int. Med. Res. 2009; 37: 1528-1542.

2. Sabirin IPR, Maskoen AM, Hernowo BS: The role of topical ethanol extract of Morinda citrifolia in wound healing in terms of CD34 immunoexpression and collagen in wistar strain rats. $M K B .2013 ; 45$ (4): 226233.

3. Orsted H, Keast D, Lalande LF, et al.: Basic principles of wound healing. Soins des Plaies Canada. 2011; 9 (2): 412.

4. Ruauw EF, Wantania FE, Leman MA: Effect of aloe vera on the closing time of the cut in the oral mucosa of the wistar rat. Pharmacon. 2016; 5 (2): 22-28.

5. Singer AJ, Clark RAF: Cutaneous Wound Healing. $N$ Engl J Med. 1999; 34 (10): 738-746.

6. Pastar I, Stojadinovic O, Yin NC, et al.: Epithelialization in wound healing. Adv Wound Care. 2014; 3 (7): 445464.

7. Priyandari Y, Umatjina SATM: Effect of jarak tree topical increase wound healing excision period of mice. Journal of Ners Community. 2015; 6 (2): 198-206.

8. Pratiwi AD, Ratnawati R, Kristianto H: Effect of clove flower bud extract (Syzygium aromaticum ) on increasing the thickness of epithelialization of incision wounds in white rats ( Rattus novergicus ) Wistar strain. FKUB Health Magazine. 2015; 2 (3): 135-143.

9. Takahashi M, Ogihara H, Nomingerel T, et al.: Repair of the surface epithelium after saponin-induced colonic mucosal injury in the rat. Medical Electron Microscopy. 1998; 31: 1-9.

10. Ricardo M, Uribe G, Saldivar S: Anti-inflammatory glycosylated flavonoids as therapeutic agents for the treatment of diabetes-impaired wounds. Curr Top Med Chem. 2015; 15 (23): 2456-2463.

11. Li K, Diao Y, Zhang $\mathrm{H}$, et al::Tannin extracts from immature fruits of Terminalia chebula Fructus Retz. promote cutaneous wound healing in rats. $B M C$ COMPLEM ALTERN M. 2011; 11 (86): 1-9.

12. Salim MN, Masyitha D, Harris A, et al.: Anti-inflammatory activity of Jatropha curcas Linn. latex in cream formulation on CD68 expression in mice skin wound. Vet. World. 2018; 11(2): 99-103.

13. Fauzi F, Salim MN, Nazaruddin N: Effectivity of Jatropha sap ointment (Jatropha curcas, Linn) on epithelialization phase of incision wound recovery on mice (Mus musculus). Jim. Vet. 2017; 1 (3): 324-333.

14. Murti DA. Salim MN, Sabri M: The effectivity of Jatropha sap ointment (Jatropha curcas, L) to 
epithelization phase of mice (Mus musculus) cutaneous wound healing with masson trichrome stain. Jim. Vet. 2017; 1 (3): 465-472.

15. Balqis U, Darmawi, Iskandar $\mathrm{CD}$, et al::Angiogenesis activity of. Jatropha curcas. L. latex in cream formulation on wound healing in mice. Vet World. 2018; 11(7): 939-943.

16. Igbinosa OO, Igbinosa EO, Aiyegoro OA: Antimicrobial activity and phytochemical screening of stem bark extract from Jatropha curcas Linn. Afr. J. Pharm. Pharmacol. 2019; 3 (2): 58-62.

17. Napanggala A, Susianti, Apriliana: Effect of Jatropha's (Jatropha curcas $L$.) topically in the level of wound healing in white rats male Sprague Dawley. Journal of the Faculty of Medicine The University of Lampung. 2014; 3 (5): 26-35.

18. Qomariah S, Lisdiana, Christijanti W: Effectiveness of ointment extract of the broken bone stem ( Euphorbia tirucalli ) on wound healing in white rat ( Rattus novergicus ) wounds. Unnes J Life Sci. 2014; 3 (2): 7986.

19. Fisher NM, Marsh E, Lazova R: Scar localized argyria secondary to silver sulfadiazine cream. Journal of the American Academy of Dermatology. 2003; 49 (4): 730732.

20. Esfahani SA, Imanieh $\mathrm{MH}$, Khoshneviszadeh $\mathrm{M}$, et $a l$ ::The healing effect of Arnebia euchroma in second degree burn wounds in the rat as an animal model. Iranian Red Crescent Med J. 2012; 14 (2): 70-74.
21. Han MC, Durmus AS, Karabulut E, et al.: Effects of Turkish propolis and silver sulfadiazine on burn wound healing in rats. Rev Med Vet. 2005; 156 (12): 624-627.

22. Homann HH, Rosbach.O, Moll W, et al.:A liposome hydrogel with polyvinylpyrrolidone iodine in the local treatment of partial-thickness burn wounds. Ann Plast Surg. 2007; 59 (4): 423-427.

23. Prasetio BF, Wientarsih I, Priosoeryanto BP: Activity of ambon banana extract in gel formulation on wound healing process of mice skin. Jurnal Veteriner. 2010; 11 (2): $70-73$

24. Versloot SMN, Vos CG, Ubbink DT, et al::Topical silver for preventing wound infection. Cochrane Database Syst Rev. 2010; 3 (CD006478): 1-20.

25. Fuadi MI, Literally U, Misnawi: The number of fibroblasts in second-degree burns in rats by applying ethanol extract gel to cocoa beans and silver sulfadiazine. e-Journal of Health Library. 2015; 3 (2): 244-248

26. Shetty S, Udupa SL, Udupa AL, et al.:Wound healing activities of bark extract of Jatropha curcas Linn in albino rats. Saudi Med. J. 2006; 27(10): 1473-1476. 